\title{
GOOD ADMINISTRATION THROUGH THE LENS OF THE CJEU: DIRECTION FOR THE ADMINISTRATIVE BODIES'
}

\author{
Réka Friedery \\ Hungarian Academy of Sciences, Centre of Social Sciences, Institute for Legal Studies
}

\begin{abstract}
The CJEU has played significant role in forming the principles applicable to administrative law, the provisions of EU treaties not being able to cover all situations. The Court re/defines the general principles of administrative law applicable to the Member States and the paper analyses the way in which these principles have been evolved and implemented.
\end{abstract}

Keywords: administrative law, principle of good administration, EU, Member States, Charter of Fundamental Rights

\section{INTRODUCTION}

With the creation of the Charter of Fundamental Rights, the Union sought to strengthen its commitment to fundamental (human) rights. The Charter outlined the general human rights policy in 50 articles, with Article 41 with the right to good administration. ${ }^{2}$ According to the Charter of Fundamental Rights, every person, that is to say, union citizen and third-country citizen, can rely to the right to good administration in their relations with European Union institutions and bodies. Also, each Member State of the European Union should concern itself with identifying and promoting the most adequate measures for ensuring good governance and good administration. In order to understand the concept of good administration, the common principles applicable to public administration are recognized and promoted especially by national and European courts. The Court of Justice's role in this field is of utmost importance, because it is the main judicial body which has played and is playing very important role in unfolding principles, among others principles applicable to administrative law, and being the interpreter of EU law. Also, the provisions of EU treaties could not and cannot cover all life-situation.

\section{THE PRINCIPLE, THE RIGHT}

The right was mentioned for the first time in the Treaty of Nice that proclaimed the first draft of the Charter of Fundamental Rights of the European Union, which became binding only on 1 December 2009 based on the Treaty of Lisbon. The explanations of the right to good administration were originally prepared under the authority of the Praesidium of the Convention which drafted

The paper was written under the aegis of the Bolyai Research Grant of the Hungarian Academy of Sciences.

With the active involvement of the EU Ombudsman, the Charter was incorporated even into the draft European Constitution. 
the Charter of Fundamental Rights of the European Union: Article $41^{3}$ is based on the existence of a Community subject to the rule of law whose characteristics were developed in the case law which enshrined inter alia the principle of good administration. ${ }^{4}$ It is important to note that the wording for that right in the first two paragraphs of Article 41 results from the case law, ${ }^{5}$ and the wording regarding the obligation to give reasons comes from Article 253 of the EC Treaty. ${ }^{6}$ The principle of good administration requires that EU law provisions are given full effect so as to achieve the result sought by the Directive (to provide for family reunification where the conditions are met) by good administrative practice. The CJEU found that Article 41 of Charter was restricted to the right to good administration by the 'institutions, bodies, offices and agencies of the Union' to whom that Article is addressed. However, the principle of the right to good administration is still applicable to Member States. ${ }^{7}$

\section{THE CJEU CASE LAW IN PROMOTING THE RIGHT TO GOOD ADMINISTRATION}

The European Court has stressed the importance of procedural guarantees as a counterbalance to administrative discretion and recognised an array of general administrative principles e.g.:

1. the principle of good administration,

2. the principle of legal certainty,

3. the principle of equality,

4. the principle of proportionality,

5. the principle of non-discrimination.

3 1.Every person has the right to have his or her affairs handled impartially, fairly and within a reasonable time by the institutions and bodies of the Union.

2. This right includes:

- the right of every person to be heard, before any individual measure which would affect him or her adversely is taken;

- the right of every person to have access to his or her file, while respecting the legitimate interests of confidentiality and of professional and business secrecy;

- the obligation of the administration to give reasons for its decisions.

3. Every person has the right to have the Community make good any damage caused by its institutions or by its servants in the performance of their duties, in accordance with the general principles common to the laws of the Member States.

4. Every person may write to the institutions of the Union in one of the languages of the Treaties and must have an answer in the same language.

4 See Court of Justice judgment of 31 March 1992 in Case C-255/90 P, Burban [1992] ECR I-2253; Court of First Instance judgments of 18 September 1995 in Case T-167/94 Nölle [1995] ECR II-2589; and 9 July 1999 in Case T-231/97 New Europe Consulting and others [1999] ECRII-2403).

5 Court of Justice judgment of 15 October 1987 in Case 222/86 Heylens [1987] ECR 4097, paragraph 15 of the grounds, judgment of 18 October 1989 in Case 374/87 Orkem [1989] ECR 3283, judgment of 21 November 1991 in Case C-269/90 TU München [1991] ECR I-5469, and Court of First Instance judgments of 6 December 1994 in Case T-450/93 Lisrestal [1994] ECR II-1177, judgement of 18 September 1995 in Case T-167/94 Nölle [1995] ECR II-258.

6 Draft Charter of Fundamental Rights of the European Union - Text of the explanations relating to the complete text of the Charter as set out in CHARTE 4487/00 CONVENT $50 \mathrm{http} / /$ www.europarl.europa.eu/charter/convent49_en.htm

7 See CJEU (Joined Cases), C-141/12 and C-372/12, YS v. Minister voor Immigratie, Integratie en Asiel, and Minister voor Immigratie, Integratie en Asiel v. M. S. 17 July 2014, paras 66 - 69. 
The EU principle of the right to good administration, requires that one should have their affairs handled impartially, fairly (transparently) and within a reasonable period of time by the institutions, bodies, offices and agencies of the Union. ${ }^{8}$ It also requires that parties to proceedings should not be penalised by virtue of the fact that they did not comply with procedural rules 'when this non-compliance arises from the behaviour of the administration itself.' ${ }^{\prime}$ Following we can see some examples of the case-law:

\section{Principle of good administration}

According to Advocate General Kokott in C-109/10 P, in accordance with the principle of good administration, the Commission has an obligation to ensure the file's proper management and safe storage. Proper management of the file includes not least the production of a meaningful index to be used for the purposes of granting access to the file at a later date.

\section{The principle of legal certainty}

According to Case C-209/96, the principle of legal certainly requires that Community rules enable those concerned to know precisely the extent of the obligations which are imposed on them, and individuals must be able to ascertain unequivocally what their rights and obligations are and take steps accordingly as recalled in Case C-143/93.

\section{The principle of equality}

The Case C 186/87 had a significant impact on the evolution of the principle of equality taking into account the discrimination criterion based on nationality. In this case, the Court stated, that as a recipient of services a tourist was entitled to take advantage of the freedom of provision of services concept set out in Article 49EC. Everyone is a potential recipient of services so every citizen crossing Member State borders inside the Community is protected by the free movement principle and the right to equal protection in the Member States he or she visits.

\section{The principle of proportionality}

In Case C-265/87, the Court of Justice of the European Union has interpreted the principle of proportionality to require that any measure of the European administration be based on law; to be appropriate and necessary for meeting the objectives legitimately pursued by the act in question; where there is a choice among several appropriate measures, the least onerous measure must be used; and the charges imposed must not be disproportionate to the aims pursued.

8 In HN the CJEU held that 'as regards the right to good administration, enshrined in Article 41 of the Charter, that right reflects a general principle of EU law'. Case C-604/12,H.N v Minister for Justice, Equality and Law Reform, Ireland 8 Mary 2014, para 50.

9 CJEU, Case C428/05, Firma Laub GmbH \& Co. Vieh \& Fleisch Import-Export v Hauptzollamt Hamburg-Jonas, 21 June 2007. 


\section{The principle of non-discrimination}

In Case C 184/99, a domestic court addressed the CJEU two preliminary questions on the interpretation of Articles 12, 17 and 18 of the Treaty establishing the European Community (TEC). The case was about a French citizen who came to study in Belgium, had been self-supporting during the first three years of study, but in the last year of study, in order to focus on the study, he applied for the so-called minimex, a social security benefit. This has been originally granted to him, but later withdrawn on the ground that he is a European Community national registered as a student. The Court ruled that if a Belgian citizen had been in the same position as the French citizen he would have received the social security benefit, hence there was a discrimination based on nationality, and ruled for the protection of all persons, regardless of their nationality, in exercising their rights and applying legal regulations equally.

\section{THE CJEU, THE ECHR AND THE RIGHT TO GOOD ADMINISTRATION}

In Case C-308/07 P the Court decided among others whether the Parliament had breached Article 20 of the Code of Good Administrative Behavior, which establishes the obligation to notify the decisions that affect the rights or interests of individuals. ${ }^{10}$ The Court dismissed that ground because the Code is not a legally binding instrument, ${ }^{11}$ even though elements of the Code overlap, however, with the fundamental right to good administration, which is enshrined in Article 41 of the Charter of Fundamental Rights of the European Union. But the Court made several very important steps unfolding the right to good administration.

The Court underlined that although the EU has not joined the European Convention on $\mathrm{Hu}$ man Rights (ECHR), which excludes, on legal grounds, a direct application of the provisions of this international convention in the Community legal order, nevertheless, the fundamental rights form an integral part of the general principles of law whose observance is ensured by the Court. To this effect, the Court draws upon the constitutional traditions common to the Member States, as well as from the guidelines provided by international instruments concerning the protection of human rights on which Member States have cooperated or which they joined. In this regard, the ECHR has a special meaning. ${ }^{12}$

The subsequent evolution of the European integration process established this case law on Article 6 (2) TEU, stating that the Union observes fundamental rights, as they are guaranteed by the ECHR signed in Rome on 4 November 1950, as well as how they result from the constitutional traditions common to the Member States, as general principles of Community law. Therefore, the ECHR provisions and the case law of the European Court of Human Rights have always been considered by the CJEU, although the EU has not yet joined the ECHR. The Court pointed to the very issue of the definition: the principle of good administration is not a single principle of the administrative law, but gathers several principles and is, in a way, a generic notion that includes all the principles

10 1. The official shall ensure that decisions which affect the rights or interests of individual persons are notified in writing, as soon as the decision has been taken, to the person or persons concerned. 2. The official shall abstain from communicating the decision to other sources until the person or persons concerned have been informed.

11 Recommended by the European Ombudsman and approved by the European Parliament.

12 Paras. $54-56$. 
of administrative law or some of these. The mentioned principle is sometimes used as a synonym for the principles related to an administrative procedure based on complying with the law. The principle of good administration requires especially the national authorities to remedy the mistakes or omissions, to carry out the procedure impartially and objectively and to make a decision within a reasonable time. Furthermore, this principle implies an extended obligation of diligence and solicitude devolving on the authorities, the right of defense, namely the obligation of agents to enable the persons concerned by a decision to express its point of view, as well as the obligation to justify the decision. ${ }^{13}$ However, the Court points to the fact that the principles coming under the concept of good administration principle vary and are not always easy to determine, and there is difficulty of evaluating whether it is about principles whose observance falls exclusively on the administrative authorities or about powers that confer individuals a subjective right to require those authorities a determined obligation of acting or not acting. ${ }^{14}$ This depends, on the one hand, on the legal nature of the original text and, on the other hand, on the normative principle resulting from the relevant provisions. It also reinforced that the case law was the main source for the formulation of Article 41 of the CFREU that transformed the principle of good administration into a fundamental right. ${ }^{15}$

\section{GOOD ADMINISTRATION: A LINK BETWEEN THE CJEU AND THE EU OMBUDSMAN}

The European Ombudsman recommended the institutions, bodies and agencies to apply rules that record the good administrative procedure for their own officials in relations with citizens. The development of principles of public administration would provide a framework for citizens to expect good administrative behaviour and set out procedural guarantees and would help citizens and officials to understand, what good and bad administrative procedure means. In order to clarify the right to good administration the European Ombudsman has drawn up the European Code of Good Administrative Behaviour, which contains guiding principles for the relationship between citizens and civil servants. In addition, the principle of good administration requires from the Community institutions and bodies the compliance with their obligations, the service-minded attitude and it ensures the appropriate treatment of citizens. The ombudsman promotes the Charter through his procedure: takes into account its principles and rules when investigates instances of maladministration. The Code of Good Administrative Behaviour was approved, with some amendments, by the European Parliament in its Resolution of 6 September 2001. This approval gives a strong legitimacy to the principles contained therein, which can subsequently be considered as applicable to all Community institutions and bodies. At present, there are at the EU institutions' level the Code of Good Administrative Behaviour and a numberof individual codes which the Community institutions, bodies and decentralised agencies have all adopted with various forms and content, some of which are textually the same as the European Code of Good Administrative Behaviour.The European Code of Good Adminisrative Behaviour sets out a number of principles which should be observed by European officials, including lawfulness (Article 4), absence of discrimination (Article 5), pro-

13 Para. 89.

14 Para. 90.

15 Para. 91. 
portionality (Article 6), consistency (Article 10), absence of abuse of power (Article 7), impartiality and independence (Article 8), objectivity (Article 9), fairness (Article 11), courtesy (Article 12), duty to reply to letters in the language of the citizen (Article 13). There are also important rules on procedure such as the obligation to notify all persons concerned of a decision (Article 20), the obligation to keep registers and the obligation to document administrative processes (Article 24). ${ }^{16}$ The special relationship with the European Court must be touched on, too. The Court considers the complaint procedure as an alternative procedure next to its own, and this is the way how the complementary role of the European office can be explained. However, the Court clearly set up the border of the Ombudsman's mandate and activity in several judgments. Thus, when an applicant referred to a draft recommendation of the ombudsman, the Court of First Instance declared that an 'act of maladministration' by the Ombudsman does not mean in itself, that the conduct constitutes a sufficiently serious breach of a rule of law within the meaning of the case-law. According to the Ombudsman, an error of legal interpretation is a form of maladministration, and in a court case the applicant relied on the ombudsman's non-binding draft recommendation which included the ombudsman's own legal interpretation of a provision, the Court of First Instance stated that the conclusive interpretation of the law is not within the remit of the Ombudsman. Thus, it did not eliminate the Ombudsman's interpretation only limited it. The Court of First Instance also pointed out that it has jurisdiction to entertain an action for compensation against the Ombudsman; it can examine the decisions and inquiries taken by the ombudsman thus has judicial control over them. This is very important because the Ombudsman has no jurisdiction to question a decision of an institution or body but as we saw the ombudsman gives his opinion even in connection with the merit of a decision. With action of damages against the Ombudsman the Court has the option to state that even the Ombudsman's actions can lead to maladministration - for whose prevention the office was established. ${ }^{17}$

\section{CONCLUSION}

The Court defined the general principles of administrative law applicable to Member State. But it is like a never-ending work, as it has analyzed time to time in its decisions the emergence and development of the good administration principle. When the principle of good administration turned into a fundamental right through the Charter of Fundamental Rights, the variety of principles under the umbrella right did forecast the continuous interpretation of this notion taking into account the ever changing life situtation. However, we shall point out that the European Ombudsman is an active participant next to the Court, as the office was created to act on behalf the European citizens, as a mediator between the EU administration and the EU citizen when their right to good administration is infringed. Thus, the right to good administration is protected by the Court and as a nonjudicial body, the European Ombudsman.

16 Council of Europe: European Commission for Democracy through Law (Venice Commissionstocktaking on the Notions of "Good Governance" and "Good Administration" Strasbourg, 9 March 2011.

17 See more FRIEDERY, R. Representing European Citizens? The EU Ombudsman's Forum in Shaping the Common European Identity. In Common European Identity in the context of current legal challenges. Bratislava : Comenius University in Bratislava, Faculty of Law, 2017, pp. 95 - 101. 


\section{Bibliography:}

Charter of Fundamental Rights of the European Union

The European Code of Good Administrative Behaviour

https://www.ombudsman.europa.eu/en/resources/code.faces\#/page/1

Draft Charter of Fundamental Rights of the European Union - Text of the explanations relating to the complete text of the Charter as set out in CHARTE 4487/00 CONVENT 50 http://www.europarl.europa.eu/charter/convent49_en.htm

Case C-209/96 United Kingdom v Commission [1998] ECR I-5655

Case C-143/93 Van Es Douane Agenten [1996] ECR I-431

Case C-265/87 Schräder v Hauptzollamt Gronau [1989] ECR I-2237

Opinion of Advocate General Kokott in Solvay SA v European Commission Case C- 109/10 P delivered on 14 April 2011, [2011] ECR I-10329

Case C-184/99 Grzelczyk v. Centre Public D’Aide Sociale D’Ottignies-Louvain-La-Neuve, [2001] ECR I-6193

Case 186/87 Ian William Cowan v Trésor public, [1987] ECR I-195

Council of Europe: European Commission for Democracy through Law (Venice Commissionstocktaking on the Notions of "Good Governance" and "Good Administration" Strasbourg, 9 March 2011.

FRIEDERY, Réka: Representing European Citizens? The EU Ombudsman's Forum in Shaping the Common European Identity. In Common European Identity in the context of current legal challenges. Bratislava : Comenius University in Bratislava, Faculty of Law, 2017, pp. 95 - 101.

\section{Contact information:}

Réka Friedery, PhD.

friedery.reka@tk.mta.hu

Hungarian Academy of Sciences, Centre of Social Sciences, Institute for Legal Studies

Tóth Kálmán u. 4.

1097 Budapest

Hungary 